This item was submitted to Loughborough's Research Repository by the author.

Items in Figshare are protected by copyright, with all rights reserved, unless otherwise indicated.

\title{
Economic and political institutions and entry into formal and informal entrepreneurship
}

PLEASE CITE THE PUBLISHED VERSION

http://dx.doi.org/10.1007/s10490-014-9381-0

\section{PUBLISHER}

(C) Springer

VERSION

AM (Accepted Manuscript)

\section{PUBLISHER STATEMENT}

This work is made available according to the conditions of the Creative Commons Attribution-NonCommercialNoDerivatives 4.0 International (CC BY-NC-ND 4.0) licence. Full details of this licence are available at: https://creativecommons.org/licenses/by-nc-nd/4.0/

\section{LICENCE}

CC BY-NC-ND 4.0

\section{REPOSITORY RECORD}

Autio, Erkko, and Kun Fu. 2014. "Economic and Political Institutions and Entry into Formal and Informal Entrepreneurship". Loughborough University. https://hdl.handle.net/2134/23023. 


\title{
Economic and Political Institutions and Entry into Formal and Informal Entrepreneurship
}

\begin{abstract}
We investigated the influence of economic and political institutions on the prevalence rate of formal and informal entrepreneurship across 18 countries in the Asia-Pacific region during the period of 2001-2010. The quality of economic and political institutions was negatively associated with entry into informal entrepreneurship and positively related with entry into formal entrepreneurship. The two types of institutions had a complementary effect on driving entry into formal entrepreneurship, whereas informal entry was influenced only individually by economic and political institutions.
\end{abstract}

Key words: informal entrepreneurship, economic and political institutions, growth aspirations 


\section{INTRODUCTION}

Institutions exercise an important influence on individual and firm-level strategic choice, and consequently, on the type and form of resulting economic activity such as entrepreneurship (Peng, Sun, Pinkham \& Chen, 2009; Peng, 2002; Peng, Wang \& Jiang, 2008; Baumol, 1990). With reference to entrepreneurial choice, the institutional framework influences who decides to pursue entrepreneurial opportunities and in which form (Levie \& Autio, 2011; Acs, Autio \& Szerb, 2013). This is important because the potential of different forms of entrepreneurial activity (e.g., formal or informal; strategic or non-strategic) to contribute to economic growth can vary considerably (Baumol, 1990; Levie \& Autio, 2011; Stenholm, Acs \& Wuebker, 2013; Acs, 2008). Thus far, however, there has been little systematic research into how institutions influence the allocation of entrepreneurial effort between different types of entrepreneurial ventures (Bowen \& de Clercq, 2008; Estrin \& Mickiewicz, 2012). In this paper we focus on a particularly consequential entrepreneurial choice - the choice between formal and informal entrepreneurship - and ask: How do a country's political and economic institutions influence the allocation of effort into formal and informal entrepreneurship?

Mounting evidence highlights important variance in the levels of informal entrepreneurship across countries (Williams \& Nadin, 2010). Informal entrepreneurs trade legal products and services, yet do not file for business registration or any incorporation documents with government authorities. The phenomenon of informal entrepreneurship (e.g., own-account workers without employee and employers with a few employees in their own informal sector enterprises) has received increasing attention from both academic scholars and policy makers (ILO, 2011a). It is seen as a potential driver of job growth and economic development, especially in developing countries. Recent survey by ILO (2011b) found that employment in the informal sector provided, on average, approximately $40 \%$ of non-agriculture employment across 39 low and middle-income 
countries. The informal sector accounts for close to $50 \%$ of non-agricultural employment in SubSaharan Africa, 51\% in Latin America and Caribbean region, and the highest rates, 58\%, are observed in South and East Asia. A large share of these would qualify as informal entrepreneurs.

Informal entrepreneurship also speaks to another important issue for less developed countries: poverty. Nearly 1.3 billion people remain below the extreme poverty line (defined as a daily income of less than US \$1.25), around two thirds of which live in Asia and the Pacific region (Wan \& Sebastian, 2011). Studies show that the fruits of progress are seldom distributed evenly, with poor people often left behind when the economy develops (Ahluwalia, Carter, \& Chenery, 1979; Anderson, 1964; Ravallion, 2007). Poverty reduction not only depends on general economic growth and increased employment, but also, on the extent to which rising income is distributed equally within the population. Because entrepreneurship enables poor people to create income, entrepreneurship provides a potential tool for redressing poverty and alleviating income inequality (Tebaldi \& Mohan, 2010).

In this study, we argue that informal sector entrepreneurship, poverty, and inequality are conditioned by a country’s economic and political institutions. Non-inclusive political and economic institutions can engender and perpetuate inequality and aggravate poverty (Acemoglu \& Robinson, 2012). Institutional qualities of society and the economy such as economic freedom (Hasan, Quibria, \& Kim, 2003), presence of policies that condition the operation of private sector (Hasan, Mitra, \& Ulubasoglu, 2007), and institutions regulating the balance of political power and the structure of bureaucratic system play an important role in either facilitating or inhibiting economic growth and alleviating poverty (Lakshman, 2003). By inhibiting economic dynamism, poorly functioning institutions can decrease the efficiency and productivity of an economy and restrict any benefits of growth to a narrow elite (Holt, 1991). 
We carry out our study using data from Asia-Pacific economies. This region has recorded impressive increases in the quality of political institutions during recent years (Puddington, 2013). This region has also experienced robust economic growth in the past decade, yet the share of informal economic activity has remained persistently high. This aspect, and the high poverty rates in the Asia-Pacific region make it a good empirical setting for us to test interactions between economic and political institutions and their impact on formal and informal entrepreneurship. To perform the analysis, we draw on the Global Entrepreneurship Monitor (GEM) dataset, which annually reports data on entrepreneurship in more than 70 countries, including most Asian countries. Because the GEM dataset is survey-based, it captures the prevalence rate of all types of start-ups, both formal and informal. Combining this dataset with the World Bank Enterprise Snapshot, which tracks formal incorporations, we develop a novel method to estimate the relative prevalence rates of both formal and informal entry in the economy. To our knowledge, this is the first wide-coverage estimate of the prevalence rates of informal entrepreneurship across countries.

We seek two major contributions with this research design. First, we contribute empirically by developing a rare estimate of the population prevalence of informal entrepreneurial entries in a wide range of national economies. This enables us to explore institutional influences on entrepreneurial activity in the informal sector across multiple countries. Thus far, studies on informal entrepreneurship have been limited to single-country studies due to the lack of robust cross-country data. Second, we contribute to the entrepreneurship literature by highlighting the important influence of political and economic institutions on formal and informal entrepreneurship. We show that the quality of political and economic institutions has a mirror symmetric effect on formal and informal entrepreneurship (the effect being of equal size and to opposite direction). Given that these two forms of entrepreneurial activity have markedly different potential effects on economic growth, this finding highlights the importance of distinguishing between the two forms of entrepreneurial activity in studies of country-level entrepreneurship. We believe that our empirical 
findings have important implications for both academic researchers and policy-makers. These are discussed in the last section of this paper.

\section{POLITICAL AND ECONOMIC INSTITUTIONS AND ENTREPRENEURIAL ACTION}

It is well known that patterns of economic behaviors - such as participation rates in entrepreneurship - can vary greatly across national contexts, and that such patterns are not attributable to country-specific differences in 'hard' economic facts alone (Autio, Pathak, \& Wennberg, 2013; Baumol, 1990; Minniti, Bygrave, \& Autio, 2006). Consequently, management and economic scholars have increasingly turned to institutional theories to better explain such crosscountry variations (Peng, Sun, Pinkham \& Chen, 2009; Peng, 2002). Considerable body of research in comparative and institutional economics has explored the effects of a country's legal and regulatory environment on economic behaviors (e.g., Djankov, Glaeser, La Porta, Lopez-de-Silanes, \& Shleifer, 2003; La Porta, Lopez-De-Silanes, \& Shleifer, 2006; La Porta \& Shleifer, 2008). Much of this work has focused on the protection of external investors (e.g., La Porta, Lopez-De-Silanes, \& Shleifer, 2008), as reflected in, e.g., financial transactions such as security issuance (e.g., Cumming, Knill, \& Richardson, 2011; La Porta et al., 2006) and the choice between debt and common stock (e.g., Lerner \& Schoar, 2005). The central notion in these studies has been that a given country's institutional setting, as reflected in the quality of its economic and political institutions, regulates the balance of benefits and costs associated with different courses of economic action, and therefore, the economic behaviors of its citizens.

Partly informed, partly inspired by this work, more recent work in comparative entrepreneurship research has begun to explore legal and regulatory influences on entrepreneurial choice (e.g., Autio \& Acs, 2010; Estrin, Korosteleva, \& Mickiewicz, 2012; Stel, Storey, \& Thurik, 2007). Consistent with the institutional economics tradition, the starting point in this work has been that the entrepreneurial choice is regulated by a country’s institutional framework (De Soto, 2002; Perry 
\& Maloney, 2007). Formal institutions represent law-based 'rules of the game' that, among other things, regulate the viability of different forms of economic transactions (Autio, 2007; Baumol, 1990; North, 1990; Stenholm, Acs, \& Wuebker, 2013). Therefore, potential entrepreneurs are influenced by their institutional setting when deciding whether or not to enter, and if yes, in which form (Bowen \& De Clercq, 2008; Estrin et al., 2012; Levie \& Autio, 2011; O’Brien, Folta, \& Johnson, 2003).

Existing comparative entrepreneurship research has studied a range of economic and legal institutions that affect entry into entrepreneurship. These include: labor market flexibility (Kanniainen \& Vesala, 2005), entry regulations (Djankov, La Porta, Lopez-de-Silanes, \& Shleifer 2002), taxation (Gentry \& Hubbard, 2000; Johnson, Kaufmann, \& Zoido, 1998), property rights regime (Autio \& Acs, 2010; Estrin et al., 2012), and bankruptcy law (Lee, Yamakawa, Peng, \& Barney, 2011). Studies have also explored the effect of a country's level of corruption and rule of law, which capture the extent to which regulations are actually enforced (Levie \& Autio, 2011). Although not specifically focused on the question of whether the entrepreneur chooses to register his or her business or not, these studies have highlighted the important role that economic institutions play in regulating the entrepreneurial choice.

Although the effect of economic institutions on entrepreneurial action has been studied quite widely, political institutions have received virtually no attention. Yet, institutional scholars have shown that political institutions can have far-reaching impact on the operation of economic systems and societal wealth creation (Acemoglu \& Robinson, 2012; Farr et al., 1998; North, 1993; Weingast, 1995; Weingast, 1997). If the inherited institutional, economic, and political framework insulates the government against democratic processes, this creates scope for misuse of government power, even outright abuse. As Weingast (1995) pointed out: “A government strong enough to protect property rights and enforce contracts is also strong enough to confiscate the wealth of its citizens". 
Mechanisms that impose credible restraints on government behaviors and incentivize government officials to comply with rules and regulations therefore need to be in place. A well-designed political system protects property rights and political freedoms, thereby encouraging citizens' participation in the economic life. Attention to these relations is therefore important to understand the effect of political institutions on different forms of entrepreneurship.

Although received studies have explored the effect of institutions on different types of entrepreneurial action, such as ‘strategic’ vs ‘non-strategic’ (e.g., Levie \& Autio, 2011), highaspiration vs low-aspiration (e.g., Stenholm, Acs \& Wuebker, 2013), and ‘opportunity’ vs ‘necessity’ (e.g., Djankov, Qian, Roland, \& Zhuravskaya, 2006), there have been only few studies on informal entrepreneurial entries (e.g., de Soto, 1989; Portes et al., 1989; Hiemstra et al., 2006; Capelleras et al., 2007). Even these have been limited to single-country settings or two-country comparisons at most (Capelleras et al., 2007). This is a major gap, given the importance of the informal sector in many countries, as cited above.

Our theoretical model considers the allocation of effort into formal or informal entrepreneurship as an occupational choice that is influenced by a country's political and economic institutions. At the individual level, entrepreneurship represents one possible use of an individual's human capital, as the individual allocates his or her labor among alternative occupational pursuits. Thus, entry into informal entrepreneurship captures an individual-level response to trade-offs and opportunity costs associated with alternative courses of action (Autio \& Acs, 2010; Cassar, 2006). Because individuals only have limited resources to allocate when making occupational choices (e.g., human, financial and social resources of their own), and because individuals seek to maximize the utility achievable with these resources, we can assume that nascent entrepreneurs choose to run their businesses formally or informally based on their calculations of the net balance of anticipated costs and benefits associated with this choice (O'Brien, Folta, \& Douglas R. Johnson, 2003). When 
the perceived benefits and costs of the informal option outweigh those associated with formal entrepreneurship, we can expect to see a larger number of informal enterprises, and vice versa ${ }^{1}$. Well-functioning institutions channel entrepreneurs' effort and resources to productive uses by reducing transactional uncertainty and reducing entrepreneurs' exposure to illegal rent expropriation by governments (McMillan \& Woodruff, 2002). If institutions impede the ability of entrepreneurs to appropriate the returns of their risk-taking, individuals will allocate their effort and resources to safer options, regardless of the consequences for the society as a whole (Baumol, 1990).

We define an informal entrepreneur as an individual actively engaged in managing a new venture that sells legitimate goods and services and is not registered with official authorities (Schneider, Buehn, \& Montenegro, 2010; Williams \& Nadin, 2010). Formal entrepreneurs are individuals who start a new venture that is registered with authorities (Webb, Bruton, Tihanyi, \& Ireland, 2012). Registration or incorporation status of the new venture is therefore used to differentiate between formal and informal entrepreneurship. We next state our formal hypotheses.

\section{Economic Institutions and Entry into Formal and Informal Entrepreneurship}

Economic institutions are those formal institutional arrangements that set and regulate the conditions for conducting business transactions in a given economy. Economic institutions relevant for entrepreneurial activity include, for example, the regulation of entry (Djankov et al., 2002); the regulation of going business concerns (Levie \& Autio, 2011); bankruptcy laws and regulations (Ayotte, 2007; Lee, Yamakawa, Peng \& Barney, 2011); and, for example, the regulation of financial markets and transactions (La Porta et al, 2006). A higher quality of these institutions

\footnotetext{
${ }^{1}$ Consistent with Institutional Economics theory, we assume that entrepreneurs are boundedly rational. Although they seek to make choices that maximize their utility, such choices are not necessarily optimal given incomplete information and cognitive limitations.
} 
would mean lighter regulation of entries and ongoing businesses, thereby reducing the cost of compliance. High-quality economic institutions would also reduce the cost of exit and facilitate access to external resources, notably, capital.

We suggest that economic institutions will exercise an important influence on the choice of whether to register one's business or not because they influence the cost of entry, the cost of doing business in a country, and the cost of exit. The quality of economic institutions, especially those pertinent to business operations in the private sector, affects the overall burden to start, operate, and close a business, and in turn, the cost incurred by potential entrepreneurs within a country (Djankov et al., 2002; Gentry \& Hubbard, 2000; Lee et al., 2011). In a business environment characterized by high-quality economic institutions, government officials adopt and implement benevolent policies that reduce regulatory burden on new businesses, and thereby, the cost of regulatory compliance. In such an environment, the cost of starting and running a new business is smaller, and entrepreneurs are therefore more likely to register their businesses in order to lock in the benefits associated with registration. These include, for example, the ability to legally own and trade property, the ability to enter formal contracts, the ability to enforce contracts through legal proceedings if necessary, and reduced risk of sanctions due to informal operation. Thus, when economic institutions are of high quality, we should see a greater rate of formal entrepreneurial entries in the economy.

Conversely, countries with low-quality economic institutions would have onerous business regulations and inconsistent implementation of these, which would place a heavy cost burden on those entrepreneurs that register their business. By keeping themselves off government registries, informal entrepreneurs are able to side-step such regulatory burden (De Soto, 2002). By not registering, informal entrepreneurs avoid the need to abide by government regulations, and also, avoid paying the fees and capital required for business permits, tax on profits, and penalty of exit, and the indirect costs associated with entrepreneur's time and efforts spent on fulfilling various 
requirements and submitting documents for formal business registration (Djankov, Lieberman, Mukherjee, \& Nenova, 2003). As compliance costs become more onerous, therefore, we should expect to see a greater number of entrepreneurs choosing not to register their businesses.

The above arguments suggest that the quality of economic institutions should have a mirror symmetric effect ${ }^{2}$ on the prevalence of entry into formal and informal entrepreneurship, respectively. We propose:

H1a: The quality of economic institutions is positively associated with the population prevalence of entry into formal entrepreneurship.

H1b: The quality of economic institutions is negatively associated with the population prevalence of entry into informal entrepreneurship.

\section{Political Institutions and Entry into Formal and Informal Entrepreneurship}

Political institutions are those formal institutional arrangements that set and regulate access to opportunity, rule of law, and the appropriability of entrepreneurial rents in a given economy. Political institutions relevant for entrepreneurial activity include, for example, the rule of law (Levie \& Autio, 2011); protection of property (Autio \& Acs, 2010); and inclusiveness in terms of equal access to opportunity, demographic representation, and equality in front of law (Acemoglu \& Robinson, 2012).

In countries with high-quality political institutions, government authorities and legislative representatives are elected through free and fair elections. High-quality political institutions are characterized by inclusive political representation without interference from military, religious,

${ }^{2}$ By 'mirror symmetric', we mean that the effects of institutional conditions on formal and informal entrepreneurship should be almost similar in magnitude and opposite in direction. 
economic, or any other powerful groups (Puddington, 2012). This ensures that no aspect of societal or economic life can be monopolized by powerful interest groups, ensuring inclusive access to opportunity. Because individuals feel secure under high-quality political institutions, fear of abuse or expropriation will not feature in their considerations of whether to register their business or not, and the balance of benefits should be tipped toward registration due to its benefits. We should therefore see a greater number of registered entries in societies characterized by inclusive political institutions.

The above tendency would be supported by the enhanced rule of law and protection of property that high-quality political institutions engender. Majority-based political institutions and consensus on the rule of law secure a fair and efficient political process, and notably, smooth and predictable changes in government which allow the elected party to make gradual policy adjustments to the country and avoids irregular and radical political regime changes and property rights violations (Feng, 2002; Li \& Resnick, 2003). Under a democratic and representative political regime, violations of property rights and abuses of privilege will be quickly punished in the electoral process, which would naturally inhibit abuses of power and violations of property rights. When the political power is allocated through a smooth and predictable electoral process, this also enhances the predictability of government policy and consistent application of the rule of law. This will enhance people’s confidence in the predictability and enforceability of economic transactions, thereby enhancing the incentives of prospective entrepreneurs to register their businesses.

In contrast, citizens in countries with poor-quality political institutions have few political rights, and even the few rights they have would be poorly protected. Under such conditions, individuals would have weak influence on the political process and perceive the application of laws and regulations as unpredictable and biased in favor of privileged elites. This would increase prospective entrepreneurs' fear of expropriation and encourage them to 'fly under the radar' by not 
registering their businesses. Furthermore, if the political institutions that enhance social stability are lacking, political systems would be vulnerable to sudden and unpredictable regime changes (Feng, 2002). This would further increase uncertainty and deduct from the willingness of entrepreneurs to invest. The risk of misappropriation of entrepreneurial returns would prompt potential entrepreneurs to choose more liquid forms of investment, such as running business informally to avoid being held hostage by radical political regimes (Root, 1996).

The above arguments suggest that the quality of political institutions should have a mirror symmetric effect on the entry density of formal and informal entrepreneurial businesses, respectively:

H2a: The quality of political institutions is positively associated with the population prevalence of entry into formal entrepreneurship.

$H 2 b$ : The quality of political institutions is negatively associated with the population prevalence of entry into informal entrepreneurship.

\section{Interaction between Economic and Political Institutions}

Above, we have considered the direct effects of the quality of economic and political institutions on the entry density of formal and informal entrepreneurial entries, respectively, arguing that the effects should be mirror symmetric. For economic institutions this was because the quality of economic institutions operates through the compliance cost of entry, operation, and exit, which will be present in registered businesses only. For political institutions this was because poor political institutions incentivize more entrepreneurs to 'fly under the radar'. Because of the nature of these mechanisms and the dichotomous nature of the choice to register the business (you either register the business or not), we expect the effects to be mirror symmetric. However, the same does not necessarily apply when we consider the joint effect of economic and political institutions on 
formal and informal entrepreneurship, respectively. The rationales behind these arguments are elaborated below.

By registering, individuals signal their intent to start and operate a new business, even if the act of registration itself would not obligate them to do so. Depending on country, there may be costs involved in the business registration, sometimes even quite substantial ones relative to GDP per capita and the amount of time and effort required. The more onerous the registration process, the less likely individuals will commit themselves to it. Importantly, once the registration has been made, a trace will be left in the registry that cannot be erased. It means that the quality of political institutions should be an important moderator of the effect of economic institutions on new business registration (Acemoglu \& Robinson, 2012; Farr et al., 1998; Friedman, 1962). Because registry markings cannot be erased, individuals will not easily commit to registration unless they are confident that the government will not suddenly impose punitive measures, such as retrospective taxes, on new business owners. Therefore, the positive effect of high-quality economic institutions on new business registration should grow stronger as the quality of political institutions goes up.

Conversely, in countries of low-quality political institutions, where there are no credible restrictions on government behavior, heavier business regulations towards entrepreneurship are more likely to be adopted and work as a tool to create rents for bureaucrats and incumbent firms (Djankov et al., 2003). For instance, established firms gain increasing influence on the political process through their contribution to the economy and building the legitimacy of the government via tax payment and job creation. To avoid severe competition and retain market position, incumbent firms are likely to exert influence through lobbying government to impose barriers for the entry and operation of entrepreneurship (Russell, Clark, \& Dwight, 2007). New businesses usually have too few resource endowments and legitimacy to influence the political process as the established firms do. Under this circumstance, the emergence and development of formal firms 
becomes very difficult, which force many potential entrepreneurs go under the radar. Therefore weak political institutions will intensify the negative effect of poor-quality economic institutions on the entry into informal entrepreneurship.

However, a similar magnitude of moderation effect should not necessarily apply to informal entrepreneurs due to the differences in the intrinsic nature of the two types of business. Registering a new business always represents a greater commitment than the choice of not register. This is because it is usually easy to launch a new, registered business if conditions change and if the informal business proves successful. De-registering an established business is more difficult. In short, once exposed, it is difficult to de-expose, but previously hidden businesses can always easily change their status by simply stepping into the limelight. Although the choice of not to register increases some hazards due to the business operating outside the rights and protections accorded to registered businesses, and the informal venture may be subject to penalties if detected by government authorities, such risks are likely to apply to unregistered businesses regardless of the quality of political institutions. Therefore, although the quality of political and economic institutions should each exercise a direct negative effect on informal entrepreneurship, we expect that the interaction effects will have different strengths, such that the interaction effect between the two types of institutions will have a weaker influence on entry into informal entrepreneurship than it does on formal entry. Supporting the reasoning above, Levie and Autio (2011) found that although the rule of law regulated positively the effect of (ease of) entry regulations on highaspiration entrepreneurship - which represent a high commitment for the entrepreneur - a similar effect was not observed for low-aspiration, low-commitment ventures. Summarizing, we hypothesize: 
H3a: The quality of political institution moderates positively the effect of the quality of economic institutions on the population prevalence of entry into formal entrepreneurship: when the quality of political institutions is high, the effect of economic institutions on formal entrepreneurship should be stronger.

H3b: The quality of political institutions moderates negatively the relationship between economic institutions and the population prevalence of entry into informal entrepreneurship. This moderation effect should be weaker for entry into informal entrepreneurship than it is for entry into formal entrepreneurship.

\section{METHODOLOGY}

We draw our sample from countries in the Asia-Pacific region, where there are 28 countries covered by the Global Entrepreneurship Monitor (GEM) Adult Population Survey (APS) during the period 2001 - 2010. Combining this with data from the World Bank, Heritage Foundation, and Freedom House, we obtain an unbalanced cross-country panel with 74 and 67 observations of the entry density of formal and informal entrepreneurship from 18 countries in the Asia-Pacific region, respectively.

\section{Variables and Measures}

We have two dependent variables. Formal entrepreneurship represents the entry rate of new firms that have been registered with government authorities (Acs, Desai, \& Klapper, 2008). It is measured as the density (i.e., population prevalence) of formal entries, relative to working-age population (ages 18-64) in a country. This data was taken from the World Bank Group Entrepreneurship Snapshot dataset. The other dependent variable is informal entrepreneurship, which represents the entry density (relative to working-age population) of unregistered entries. We 
developed a novel method to estimate the entry density of informal entrepreneurial activity (Autio \& Fu, 2012).

We estimate the entry density of informal entrepreneurs (i.e. owner-managers of operating business less than 42 months old) using the GEM data. GEM conducts representative adultpopulation surveys annually, using randomized cluster sampling of at least 2000 individuals per country. The entrepreneurial activities surveyed by GEM include any form of entrepreneurial entry, including registered and unregistered entities, including self-employment. This survey data provides annual estimates of the overall prevalence of entrepreneurial entries within a given population in the observation period.

We derive the yearly entry new entrepreneurs (i.e., the total entry density) '?' by assuming the following. First, the entry rate ' $?$ ' is assumed to be constant over the past 3.5 years for a given country. Second, the survival rate over time takes an exponential form:' ${ }^{\beta n}$, in which ' $t$ ' refers to the age of the firm in the year of observation. ' $\bar{\Sigma}$ ' refers to the rate parameter of the exponential distribution. Third, the survival rate of year of observation is an estimated variable and set at 0.5 for all countries (data collection in June, no exit is assumed within the first 0.5 years). We solve the simultaneous equations below and get '? ' and ' $\bar{\Sigma}$ ':

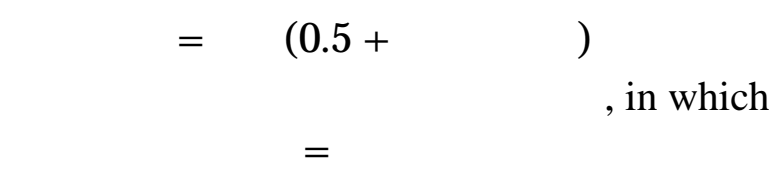

$\mathrm{x}$ ' $\mathrm{y}_{\mathrm{m} 2 \mathrm{~m}}$ ' is the population density of new entrepreneurs. New entrepreneurs are ownermanagers of new businesses that have paid salaries, wages, or any other payments to the owners for up to 42 months. 
$\mathrm{x}$ ' $\mathrm{y}_{\mathrm{z} \mathbf{m} \mathrm{m} \eta_{\mathrm{o}}}$ ' is the population density of established firms and measured by the population density of owner-managers of new businesses that have paid salaries for longer than 42 months per.

$x \quad ?{ }^{\prime}{ }^{3}$ is the entry density of new entrepreneurs in the year of observation.

$\mathrm{X}$ ' $\bar{\Sigma}$ ' is the rate parameter of the exponential distribution of the survival rate.

We supplement the GEM data with the World Bank Entrepreneurship Snapshots dataset on the entry density of registered business, i.e., ‘३’. Finally, we obtain the entry density of informal entrepreneurship by subtracting ‘३’ from total entry density of new entrepreneurship ‘? ’.

The independent variables are the quality of economic institutions, which represents the overall burden of regulation and the efficiency of government in the business regulatory process. It is measured by the Business Freedom index composed by the Heritage Foundation. This index is a composite of 10 equally weighted factors regarding the time, cost and number of procedures required to start a business, to obtain a license, and to close a business based on data from World Bank’s Doing Business dataset. The values of this index range between 0 and 100, with 100 indicating the highest level of institutional quality (Klapper, Lewin, \& Delgado, 2009). The quality of political institutions captures the degree of freedom in the electoral process, political pluralism and participation, and functioning of government. It is measured by the "political rights" index from the annual Freedom in the World Survey by Freedom House. The scale goes from of 1 to 7, with 7 representing the highest quality of political institutions (Kawai \& Urata, 2002; Shane, 1996).

We controlled for several macro-economic factors associated with the national level of entrepreneurial activities. The list of control variables includes the country's annual GDP growth

${ }^{3}$ GEM provides individual-level data. We obtain business-level data by dividing individual-level entry density with the average number of owners of new ventures on a country-year basis. 
rate and the country's level of GDP (billions of USD) adjusted for purchasing power parity (ppp), as country's economic performance and growth rate have been shown to be positively related with entrepreneurial activities (Davidsson, Lindmark, \& Olofsson, 1994; Levie \& Autio, 2011) ${ }^{4}$. We also included the size of working-age population (millions) and the annual growth rate of a country’s population in order to capture the status of labor market, the size and potential of the domestic market and supply of entrepreneurs (Levie \& Autio, 2011; Reynolds, Storey, \& Westhead, 1994). These data were taken from the World Bank datasets. Finally, to control for domestic industry structure and domestic competition, we controlled for the population density of established entrepreneurs (i.e., owner-managers of established businesses older than 3.5 years old) (Levie \& Autio, 2011). This measure was taken from the GEM dataset that registers all entrepreneurial activity, formal and informal, that has paid wages and salaries for longer than 42 months ${ }^{5}$.

\section{Statistical Analysis}

Our key explanatory variables represent institutional conditions, which change relatively slowly. We therefore first checked whether there was sufficient variance in these variables to justify a panel design over a pooled or cross-sectional OLS design. On average, the country-level variance in economic and political institutions over the study period was about $23 \%$ and $11.5 \%$, respectively, relative to the overall variance in the dataset. This significant amount of variance warranted the adoption of panel regressions (Levie \& Autio, 2011).

Our empirical models operate at the country level of analysis. We have two linear regression models with each modeling a different, partly related dependent variable (i.e., population

\footnotetext{
${ }^{4}$ We did not control for GDP per capita because this correlated strongly with the quality of political and economic institutions. However, the joint effect of population size and GDP level indirectly captures this effect.

5 The 42-month time limit comes from the timing of GEM Adult Population Surveys. These are typically in May-June. One survey question asks whether the entrepreneurs have paid salaries to anyone for longer than the three previous calendar years. $3 * 12$ months +6 months is 42 months.
} 
prevalence of formal and informal entrepreneurship in a country, respectively) on a set of independent variables. If the two models were unrelated, we would be able to estimate them separately. However, there are good theoretical grounds to expect that registered and unregistered entrepreneurial entries are partial substitutes (although not full substitutes) of one another (Godfrey, 2011). This means that it is possible to gain a more efficient estimator by estimating the two equations jointly (Zellner, 1962). To perform our analysis, we therefore ran a system of seemingly unrelated regressions (SUR). This approach assumes the two equations to be partially related through their error terms. To verify this, we conducted a Breusch-Pagan test of independence of error terms of the two regressions. The null hypothesis was rejected (chi2 $(1)=3.006, \operatorname{Pr}=0.08$ ), suggesting that the residuals of the two models were correlated. The choice of a seemingly unrelated regression approach was therefore justified. More specifically, we tested our hypotheses using the SUR approach for unbalanced panel data. The Hausman test was carried out to test the null hypothesis that the coefficients estimated by the efficient random-effect estimators are the same as those estimated by the consistent fixed-effect estimators $\left(\mathrm{Chi}^{2}(7)=2.71, \mathrm{p}>0.1\right)$. In the current case, we could not reject the null hypothesis. The Hausman test suggested that our model did not have any omitted variables that were strongly correlated with the explanatory variables, implying that a random-effect specification would produce more efficient estimation by including all information in data captured by both time-variant and time-invariant explanatory variables. To control for potential multicollinearity, we checked the variance-inflation factors (VIFs) of the variables in the models. The maximum value of VIF was 3.26 (less than 10) and the mean VIF was 2.18 (less than 6), suggesting multicollinearity was not a problem in our data.

All variables included in the regression models were standardized with a mean of 0 and a standard deviation of 1 . As a robustness check, we ran pooled OLS, and the results remained effectively the same as those estimated using panel regressions. As an additional robustness check, we extended the current sample beyond Asia-Pacific countries and included, in total, 67 countries 
worldwide. Our findings exhibited similar patterns to those based on Asia and the Pacific country sample (see Table 3B).

\section{RESULTS}

Table 1 reports country average of population prevalence of entry into formal and informal entrepreneurship (i.e., number of formal or informal entries per 100 working-age people) over the period $2001-2010^{6}$.

\section{Insert Table 1 about here}

The figures in Table 1 indicate considerable variance in the population prevalence of informal entrepreneurship across countries. In our dataset, African countries rank the highest in the population prevalence of informal entrepreneurship (3.98 informal-sector entries annually per 100 adult-age individuals), while OECD countries rank the lowest (0.62). The entry rate of informal entrepreneurship in Asia and the Pacific countries is about 2.03 (2.46 when OECD countries from this region are excluded).

Table 2 reports descriptive statistics and correlations of the variables included in the models. The findings based on the sample of Asia and the Pacific countries are shown in Table 3A. Table 3B reports the results of the robustness test based on the larger sample of 67 countries worldwide. Models 1 and 4 are specified as the baseline models including only control variables. Models 2 and 5 include the two explanatory variables and test Hypotheses 1 and 2, which posit the main effects of economic and political institutions on entry into formal and informal entrepreneurship, respectively.

\footnotetext{
${ }^{6}$ Due to partly non-overlapping data between the GEM survey and the World Bank Enterprise Survey, the estimate of entry into informal entrepreneurship does not cover the complete 10-year time frame for all countries in our sample.
} 
Models 3 and 6 test the moderation effects between economic and political institutions, as proposed in Hypothesis 3.

Insert Table 2 about here

For the estimation results based on sample of Asia-Pacific countries, Model 2 in Table 3A shows that, as predicted, the quality of economic and political institutions is positively associated with formal entrepreneurship $(0.3, \mathrm{p}<0.1 ; 0.43, \mathrm{p}<0.05)$ and negatively associated with informal entrepreneurship (-0.18, $\mathrm{p}<0.05 ;-0.21, \mathrm{p}<0.05)$. These results mean that holding all other variables constant, one standard deviation increase in the quality of economic institutions leads to about 0.3 standard deviation increase in entry into formal entrepreneurship and a 0.18 standard deviation decrease in entry into informal entrepreneurship. In other words, with every increase of about 16 points in the value of the economic institutions quality index, formal entry density will increase by about 0.18 , or about 1 entry out of 570 working-age population. Similarly, informal entry density will decrease by about 0.29 , or about 1 entry out of 349 working-age population. More intuitively, if a country's formal and informal entry rate equals the value of the sample mean in a given year (i.e., 0.48 and 1.25), the 16-point increase in the quality of the country's economic institutions would result in a $37 \%$ increase in the formal entrepreneurship entry rate and a $23 \%$ decrease in the informal entrepreneurship entry rate in the country while keeping other explanatory variables constant.

Furthermore, a one standard-deviation increase in the quality of political institutions would lead to a roughly 0.43 standard-deviation increase in entry into formal entrepreneurship and a 0.21 standard-deviation decrease in entry into informal entrepreneurship. More precisely, with every increase of about 2.3 points in the scale of political institution quality index, there will be an increase of about 1 entry into formal entrepreneurship out of every 398 working-age adults and a decrease of about 1 entry into informal entrepreneurship out of every 299 working-age adults. A 
comparison between the quality of political institutions in India (4.3) and Malaysia (2.0) would illustrate this contrast. Put another way, for countries where the formal and informal entry rate equals the sample mean (i.e., 0.48 and 1.25) at a given point in time, this increase of 2.3 points in the quality of political institutions would lead to an almost 53\% increase and 27\% decrease in the entry rate into formal and informal entrepreneurship, respectively. Given that only a fraction of the adult-age population is trying to start new businesses at any given time, and given that once started, the businesses are going to be active for some time, the impact of economic and political institutions is of practical significance on entry into both formal and informal entrepreneurship. Hypotheses 1 and 2 are therefore supported.

As shown in Model 3 from Table 3A, entry into formal entrepreneurship is encouraged by interaction between political and economic institutions $(0.32, \mathrm{p}<0.01)$, while entry into informal entrepreneurship is not affected (-0.11, $\mathrm{p}>0.1)$. The magnitude of the interaction effects on informal entry is much weaker than in the case of formal entry (0 vs. 0.32) at face value. We conducted onesided $\mathrm{z}$ test on the cross-equation constraint $\left(\mathrm{H}_{0}\right.$ : the coefficient of the interaction term in the informal entry model is smaller than it is in the formal entry model) after we performed seemingly unrelated regressions and verified that the moderating effect is indeed significantly weaker in the informal entry model than it is in the formal entry model $(p=0.851)^{7}$. Hypothesis 3a is thus supported while Hypothesis $3 \mathrm{~b}$ is only partially supported. The coefficients for economic and political institutions in this case reveal a conditional relationship, meaning that when the quality of economic institutions is at its mean value (i.e. 72.8), an increase in the quality of country's political institutions by 2.3 points on a 7-point scale will produce an increase of 0.18 in the population prevalence of entry into formal entrepreneurship. This translates to about 1 entry out of 570

\footnotetext{
${ }^{7}$ We conducted a similar test using the larger sample of 67 countries worldwide $(\mathrm{p}=0.802)$ and reached the same conclusion.
} 
working-age population, or about 37\% increase in the prevalence rate of formal entrepreneurship relative to the mean value in the Asia-pacific country sample. Similarly, when the quality of political institutions is at its mean value (i.e. 3.49), one standard-deviation increase in the quality of country's economic institutions (i.e., about 16 points on a 0-100 point scale) will increase population prevalence of entry into formal entrepreneurship by 0.26 , which is about 1 formal entry our of 388 working-age population, corresponding to a 54\% increase in the prevalence rate of formal entrepreneurship relative to the mean value in Asia-Pacific countries in our sample.

A graphical representation of the interaction effect between political and economic institutions on entry into formal entrepreneurship is displayed in Figure 1. The interaction is plotted as the relationship between the quality of economic institutions and entry into formal entrepreneurship at low (one standard deviation below the mean), medium (mean) and high (one standard deviation above the mean) levels of political institutions (Aiken \& West, 1991; Cohen \& Cohen, 1983). The figure shows clearly that when the quality of political institutions is higher, economic institutions exert a more positive effect on the population prevalence of formal entrepreneurship.

Insert Table 3A and Table 3B about here

Insert Figure1 about here

\section{DISCUSSION AND CONCLUSION}

The significance of the 'informal economy’ has been widely recognized among development economists since Lewis’ (1954) pioneering work over half a century ago. However, management scholars have only recently started to explore this topic (Godfrey, 2011; Webb et al., 2009). Therefore, although there exists a significant body of sociological, ethnographic, institutional, and comparative economic research on the informal economy (e.g., De Soto, 2002; 
Djankov et al., 2003; Williams, 2006, 2008), relatively little is known about the processes underlying value creation and economic dynamism in this context (Estrin \& Mickiewicz, 2012). Specifically, our understanding of the origins and country-level dynamics of informal entrepreneurship has been deficient, due to the dearth of datasets tracking informal-sector entrepreneurial activity across countries. We have addressed this gap by employing a novel method to estimate the scale of informal-sector entrepreneurial activity at the country level and by exploring the influence of political and economic institutions on the allocation of effort into informal-sector entrepreneurial activity.

Our findings show that the quality of political and economic institutions each exercise a direct, independent influence on the form entrepreneurial entries: if institutions are lacking in quality, more entrepreneurs will choose not to register and fly under the radar. Depending on the quality of political institutions, economic institutions can have varying effects on entry into formal entrepreneurship. This finding is consistent with Baumol (1990), who argued that the supply of entrepreneurs is largely constant, and institutions mostly regulate the form their efforts take. Only when both economic and political freedoms prevail, there will be higher rates of formal entries. Our findings also echo those reported by Levie and Autio (2011), who found the rule of law and regulation of entry to exercise a joint effect on 'strategic' entrepreneurial entries but not on lowcommitment entrepreneurial entries. While consistent with the Baumolian hypothesis, our findings also signal that entrepreneurs are sensitive to external institutional conditions. Thus, countries cannot fully substitute, e.g., for low-quality political institutions with higher-quality economic institutions. These findings, if upheld in further analysis, provide for interesting implications both for theory and policy practice.

It is worth noting in Figure 1 that when low-quality economic institutions combine with high-quality political institutions, entry into formal entrepreneurship is deterred more than when 
they combine with low-quality political institutions. In other words, when the quality of economic institutions is low, low-quality political institutions would give rise to a relatively higher level of entry into formal entrepreneurship than high-quality political institutions would. One explanation of this pattern is that countries with low-quality political institutions could feature "political entrepreneurship” - i.e., rent-seeking and even exploitative entrepreneurs who politically manipulate access to and monopolize opportunities, resulting in the transfer of wealth to themselves, as opposed to “market entrepreneurship” (Holcombe, 2002). As Holcombe noted: “...if the political support lost from those who pay for the transfer is less than the political gain in support from the recipients, then the political entrepreneur can profit from such a forced transfer". In countries with lower-quality political institutions, government can coerce the public for the benefit of small elites who control access to political power. With increases in the quality of economic institutions, political entrepreneurship becomes less prevalent in those countries, as political rent-seeking may become more difficult and less beneficial. Similarly, the positive relationship between the quality of economic institutions and formal entrepreneurship under a highquality political institutions can be interpreted as political entrepreneurs finding fewer opportunities within a country with better of political institutions. Instead, productive market entrepreneurship would prevail with improved quality of economic institutions.

Our findings are timely, since they respond to recent calls by some management scholars for greater attention to the informal economy (Godfrey, 2011; Webb et al., 2009). Although a subject of interest for development economists, management scholars have only recently started to explore this topic. Interest in this topic has been partly sparked by the observation that instead of representing a passing phenomenon of economic development, as Lewis (1954) originally suggested, informal economy is very much a permanent feature of virtually any economy, and it is therefore important to understand the implications of this phenomenon for management as well as the broader economy (e.g., Becker, 2004; De Soto, 1989, 2000; Piggott \& Whalley, 2001). In this 
regard, and continuing on the Baumolian theme, one important implication concerns the allocation of entrepreneurial effort: does informal entrepreneurship represent a 'misallocation' of effort that could, under different conditions, have been allocated to formal (and thus, presumably more productive) entrepreneurship? Or, as Godfrey (2011) put it, when do informal entrepreneurial efforts substitute for, and when do they complement formal entrepreneurship?

The pattern of our findings suggests that formal and informal entrepreneurial entries may substitute for one another under some conditions but not always. Overall, the mirror symmetric direct pattern is suggestive of a substitution effect: if institutional conditions are lacking, more prospective entrepreneurs may opt not to register their businesses. This choice would represent a clear substitution effect for nascent entrepreneurs, with negative consequences for economic productivity. As informal entrepreneurs lack the kind of property protections and legal status accorded to formal entrepreneurs, failure to register can act as a powerful disincentive against capital accumulation and investment (Licht \& Siegel, 2006). Thus, informal entrepreneurs may lock themselves into a low-productivity mode (Giannetti \& Simonov, 2009). Such effects may become entrenched, as a widespread shadow economy can become a source of unfair competition for formal-sector companies, to the extent that these operate in the same market (Estrin et al., 2012; Williams, 2005).

However, the notion of substitutability would probably be oversimplifying in our data, since we cannot isolate the effect of institutions on the choice to enter, one the one hand, and on the choice to register once entered, on the other. We have formulated our hypotheses on the choice of whether or not to register, not whether or not to enter. Addressing the substitutability question would require individual-level observations of the registration choice and a design that permits the statistical control of selection bias introduced through entry decisions. The non-symmetric joint effect of economic and political institutional quality on the registration decision suggests that full 
substitutability cannot be operating in our data. We speculate that, in particular, the effect of lowquality political institutions on informal entry probably does not operate through a substitution effect, since an important aspect of deficient political institutions is the monopolization of opportunity. In the Mubarak-dominated Egyptian economy, for example, a large number of informal entrepreneurs were probably pushed to informal entrepreneurship because elites had turned large swaths of the country's economy into a private privilege. Because of this, individuals who might not have started new businesses in the first place were forced to do so in the absence of alternative means of making a living. This is only speculation, however, and more research with appropriate individual-level data and designs is required to address the substitutioncomplementarity challenge introduced by Godfrey (2011).

The question of substitutability versus complementarity is important, because empirical evidence suggests that informal entrepreneurship may act both as a symptom and as a safety valve that both reflects the poor quality of economic and political institutions, and also, mitigates the effect of these on the poor. On the one hand, poorly functioning economic and political institutions may push deprived individuals into entrepreneurship by excluding them from access to opportunity and employment in the formal sector. Supporting this, Byung-Yeon (2005) found that poorer households and households that need more additional income in Romania were more likely to participate in informal economy. On the other hand, when formal institutional arrangements fail to function properly, firms may resort to informal operation in order to reduce uncertainty and retain constancy (Peng, 2002). In low-quality institutional contexts, informal entrepreneurship may act as a safety valve that mitigates the negative effects of opportunity exclusion by serving as a source of income for the poor ((Peng \& Heath, 1996; Peng, Sun, Pinkham, \& Chen, 2009; ESCAP, 2006). A study of Anderson (1998) showed that although the estimated incidence of poverty in Ulanabaatar was 38 per cent in 1996, it could have been 53 per cent in the absence of income from the informal sector there. Similarly, Reddy found that there had been a significant increase in the incomes and 
assets of those involved in the informal sector compared to their pre-informal sector days in Fiji (Reddy, 2007). Thus, although informal sector entrepreneurship may be an expression of poverty, it may also mitigate the negative effects of poverty, as experienced by individuals.

On the other hand, while informal entrepreneurship may mitigate poverty at the level of the individual, it may also perpetuate economic inefficiency at the country level. Evidence suggests that most informal businesses are small in scale, lack capital, are not technologically advanced, employ unskilled labor, and have low productivity and low savings rates (ILO, 1991, 1993, 2002). Thus, informal entrepreneurship may easily trap individuals into a low-paid, low-skilled, and insecure work with little potential for progression (Oxfam, 2012). By not registering, informal entrepreneurs try and 'fly under the radar' and avoid growing to a large size so as to escape the attention and scrutiny of authorities (Fajnzylber, Maloney, \& Montes-Rojas, 2011). While informal entrepreneurs can be innovative (Daniels, 2010; ILO, 1992), they rarely innovate systematically or upgrade their technological capabilities to pursue innovation-driven growth (OECD \& Eurostat, 2005). Finally, informal entrepreneurs may act as a source of unfair competition for formal-sector entrepreneurs, who have to comply with regulations. As an important side effect, thus, informal-sector entrepreneurship may even undermine formal-sector activity (Williams, 2005).

Although the question of substitutability versus complementarity remains open, the positive joint effect observed for political and economic institutions on formal entries nevertheless sends an important signal for policy-makers. As noted above, while there is increasing evidence that while informal entrepreneurship plays important and varied role in the economy, it may also create undesirable negative externalities - notably, reduced productivity growth and unfair competition. Thus, the accepted policy preference - at least in OECD (Ahmad \& Hoffmann, 2008) - is that formal registration should be encouraged. Our findings suggest that piecemeal improvements in some aspects of the institutional setting are less likely to be effective than coordinated, orchestrated 
actions that simultaneously address many aspects of the entrepreneurial framework conditions (Acs, Autio, \& Szerb, 2013) - in our case, both political and economic institutions. In other words, improvements in economic institutions alone may not be sufficient to unleash the full economic potential of entrepreneurship if the quality of political institutions lacks behind.

One important aspect of our findings concerns the directionality of causality in institutions entrepreneurial choice relationships. In our theorizing, we have assumed that institutions engender and shape economic action: it is institutional conditions that drive some individuals to choose not to register. In their recent paper, Estrin and Mickiewicz argued (consistent with Argandona (1999)) that the causality may also work to the other direction: that informal entrepreneurship may promote lawlessness and lead to gradual erosion in institutional quality (Estrin \& Mickiewicz, 2012). They explored the effect of the shadow economy on the growth orientation of entrepreneurial new firms, using GEM data and the Schneider (2009) estimate of the size of the shadow economy, and found a curvilinear (â ) effect of the shadow economy on the prevalence of entrepreneurial entries. They interpreted the rise of entrepreneurial entries at high levels of the shadow economy as a possible sign of the gradual institutionalization of the shadow economy and the gradual breakdown in the rule of law. Future research should address the direction of this causality, ideally, using longitudinal panel designs.

Finally, although we have evoked alleviation of poverty at the individual level as a possible positive effect of informal entrepreneurial activity, our data has not permitted us to test this effect. Our data being country-level estimates, individual-level welfare effects have eluded our examination. This question is best addressed with individual-level data.

The above limitations notwithstanding, this paper has demonstrated important effects of country-level institutional conditions on both formal and informal entrepreneurship. Because our country-level variables are amenable to manipulation through policy action, they should offer food 
for thought for Asia-Pacific policy-makers seeking to harness the full potential of entrepreneurial processes for the benefit of economic and productivity growth. Theoretically, the core finding reported in this paper concerns the mirror symmetry in direct effects and asymmetry in joint effects. We have provided, to our knowledge, the first estimation of the size of the informal entrepreneurial sector in Asia-Pacific economies, thereby shedding light on an aspect of the economic landscape that is likely to be particularly consequential for efforts of poverty alleviation. We hope that this initial inquiry will inspire follow-on studies focusing on this important phenomenon.

\section{REFERENCES}

Acemoglu, D., \& Robinson, J. A. 2012. Why nations fail: The origins of power, prosperity and poverty. London: Profile Books.

Acs, Z. J., \& Amorós, J. E. 2008. Entrepreneurship and competitiveness dynamics in Latin America. Small Business Economics, 31(3): 305-322.

Acs, Z., Autio, E., \& Szerb, L. 2013. National systems of entrepreneurship: Measurement issues and policy implications. Public Policy Research Paper No. 2012-08, George Mason University, VA. Available at SSRN: http://ssrn.com/abstract $=2008160$ or http://dx.doi.org/10.2139/ssrn.2008160.

Acs, Z., Desai, S., \& Klapper, L. 2008. What does “entrepreneurship” data really show? A comparison of the Global Entrepreneurship Monitor and World Bank Group Datasets. Small Business Economics, 31(3): 219-239.

Ahluwalia, M. S., Carter, N. G., \& Chenery, H. B. 1979. Growth and poverty in developing countries. Journal of Development Economics, 6(3): 299-341.

Ahmad, N., \& Hoffmann, A. 2008. A framework for addressing and measuring entrepreneurship OECD statistics. Working Paper No. 2. Paris: OECD.

Aiken, L. S., \& West, S. G. 1991. Multiple regression: Testing and interpreting interactions. Thousand Oaks, CA: Sage.

Anderson, J. H. 1998. The size, origins, and character of Mongolia's informal sector during the transition. Policy Research Working Paper, No. 1916. Washington, DC: World Bank.

Anderson, W. H. L. 1964. Trickling Down: The relationship between economic growth and the extent of poverty among american families. The Quarterly Journal of Economics, 78(4): 511-524.

Argandona, A. 1999. Business ethics in Spain. Journal of Business Ethics, 22(3): 155-173. 
Audretsch, D., \& Keilbach, M. 2004. Entrepreneurship and regional growth: An evolutionary interpretation. Journal of Evolutionary Economics, 14(5): 605-616.

Autio, E. 2007. GEM 2007 global report on high-growth entrepreneurship. London, UK: Babson College and London Business School.

Autio, E., \& Acs, Z. 2010. Intellectual property protection and the formation of entrepreneurial growth aspirations. Strategic Entrepreneurship Journal, 4(3): 234-251.

Autio, E., \& Fu, K. 2012. Allocation of effort into informal entrepreneurship: Institutional and individual-level effects. Working Paper. London: Imperial College Business School.

Autio, E., Pathak, S., \& Wennberg, K. 2013. Consequences of cultural practices for entrepreneurial behaviors. Journal of International Business Studies, 44(4): 334-362.

Baumol, W. J. 1990. Entrepreneurship: Productive, unproductive, and destructive. Journal of Political Economy, 98(5): 893-921.

Becker, K. F. 2004. The informal economy. Stockholm: Swedish International Development Agency.

Bowen, H. P., \& De Clercq, D. 2008. Institutional context and the allocation of entrepreneurial effort. Journal of International Business Studies, 39(1): 1-21.

Byung-Yeon, K. 2005. Poverty and informal economy participation. Economics of Transition, 13(1): 163-185.

Cassar, G. 2006. Entrepreneur opportunity costs and intended venture growth. Journal of Business Venturing, 21(5): 610-632.

Cohen, J., \& Cohen, P. 1983. Applied multiple regression/correlation analysis for the behavioral sciences. Hillsdale, NJ: Lawrence Erlbaum Associates.

Cumming, D. J., Knill, A. M., \& Richardson, N. T. 2011. Firm size, institutional quality and the impact of securities regulation. Working paper. Available at SSRN: http://ssrn.com/abstract=1572655 or http://dx.doi.org/10.2139/ssrn.1572655.

Daniels, S. 2010. Making do: Innovation in Kenya's informal economy. New York: Analogue Digital.

Davidsson, P., Lindmark, L., \& Olofsson, C. 1994. New firm formation and regional development in Sweden. Regional Studies, 28(4): 395-410.

De Soto, H. 1989. The Other Path: The invisible revolution in the Third World. New York: Harper and Row.

De Soto, H. 2000. The Mystery of Capital: Why capitalism triumphs in the West and fails everywhere else. London: Black Swan.

De Soto, H. 2002. The Other Path: The economic answer to terrorism. London: Harper and Row. 
Djankov, S., Glaeser, E., La Porta, R., Lopez-de-Silanes, F., \& Shleifer, A. 2003. The new comparative economics. Journal of Comparative Economics, 31(4): 595-619.

Djankov, S., La Porta, R., Lopez-de-Silanes, F., \& Shleifer, A. 2002. The regulation of entry. Quarterly Journal of Economics, 117: 453-517.

Djankov, S., La Porta, R., Lopez-de-Silanes, F., \& Shleifer, A. 2003. Courts. The Quarterly Journal of Economics, 118(2): 453-517.

Djankov, S., Lieberman, I., Mukherjee, J., \& Nenova, T. 2003. Going informal: Benefits and costs. In Belev, B. (Ed.), The informal economy in the EU accession countries: Size, scope, trends and challenges to the process of EU enlargement. Sofia, Bulgaria: Center for the Study of Democracy.

Djankov, S., Qian, Y., Roland, G., \& Zhuravskaya, E. (2006). Who are China's entrepreneurs? The American Economic Review, 96(2): 348-352.

Economic and Social Commission for Asia and The Pacific. 2006. Poverty and the informal sector: Role of the informal sector in poverty reduction. Committee on Poverty Reduction (Third Session), Bangkok, Thailand, 29 November 2006 - 1 December 2006. http://www.unescap.org/pdd/CPR/CPR2006/English/CPR3_1E.pdf. Accessed on Aug. 01,2013

Estrin, S., \& Mickiewicz, T. 2012. Shadow economy and entrepreneurial entry. Review of Development Economics, 16(4): 559-578.

Estrin, S., Korosteleva, J., \& Mickiewicz, T. 2013. Which institutions encourage entrepreneurial growth aspirations? Journal of Business Venturing, 28(4): 564-580.

Fajnzylber, P., Maloney, W. F., \& Montes-Rojas, G. V. 2011. Does formality improve micro-firm performance? Evidence from the Brazilian SIMPLES program. Journal of Development Economics, 94(2): 262-276.

Farr, W. K., Lord, R. A., \& Wolfenbarger, J. L. 1998. Economic freedom, political freedom, and economic well-being: A causality analysis. CATO Journal, 18(2): 247-262.

Feng, Y. 2002. Political freedom, political instability, and policy uncertainty: A study of political institutions and private investment in developing countries. International Studies Quarterly, 45(2): 271-294.

Friedman, M. 1962. Capitalism and freedom. Chicago: University of Chicago Press.

Gentry, W. M., \& Hubbard, R. G. 2000. Tax policy and entrepreneurial entry. The American Economic Review, 90(2): 283-287.

Giannetti, M., \& Simonov, A. 2009. Social interactions and entrepreneurial activity. Journal of Economics \& Management Strategy, 18(3): 665-709.

Glaeser, E. L., La Porta, R., Lopez-de-Silanes, F., \& Shleifer, A. 2004. Do institutions cause growth? Journal of Economic Growth, 9(3): 271-303. 
Godfrey, P. C. 2011. Toward a theory of the informal economy. The Academy of Management Annals, 5(1): 231-277.

Hasan, R., Mitra, D., \& Ulubasoglu, M. 2007. Institutions and policies for growth and poverty reduction: The role of private sector development. Asian Development Review, 24(1): 69116.

Hasan, R., Quibria, M. G., \& Kim, Y. 2003. Poverty and economic freedom: evidence from crosscountry data. East-West Center working papers. Economics series, No. 60. Honolulu: EastWest Center.

Holcombe, R. G. 2002. Political entrepreneurship and the democratic allocation of economic resources. The Review of Austrian Economics, 15(2): 143-159.

Holt, S. L. 1991. The role of institutions in poverty reduction. Policy Research Working Paper Series, No. 627. Washington, DC: World Bank.

ILO. 1991. The dilemma of the informal sector, International Labour Conference, Report of the Director General. Geneva: ILO.

ILO. 1992. Technological capability in the informal sector - Metal manufacturing in developing countries. Geneva: ILO.

ILO. 1993. Fifteenth International Conference of Labour Statisticians: Resolution concerning statistics of employment in the informal sector adopted by the Fifteenth International Conference of Labour Statisticians. Geneva: ILO.

ILO. 2002. Decent work and the informal economy. Report VI for the 90th International Labour Conference. Geneva: ILO.

ILO. 2011a. Employment in the informal economy, Key Indicators of the Labour Market (KILM), 7th Edition. Geneva: ILO.

ILO. 2011b. Statistical updates on employment in the informal economy. Geneva: ILO.

Johnson, S., Kaufmann, D., \& Zoido, P. 1998. Regulatory discretion and the unofficial economy. American Economic Review, 88(2), 378-392.

Kanniainen, V., \& Vesala, T. 2005. Entrepreneurship and labor market institutions. Economic Modelling, 22(5): 828-847.

Kawai, H., \& Urata, S. 2002. Entry of small and medium enterprises and economic dynamism in Japan. Small Business Economics, 18(1-3): 41-51.

Klapper, L., Lewin, A., \& Delgado, J. M. Q. 2009. The impact of the business environment on the business creation process. Policy Research Working Paper, No. 4937. Washington, DC: World Bank.

La Porta, R., \& Shleifer, A. 2008. The unofficial economy and economic development, NBER Working Paper No. 14520. 
La Porta, R., Lopez-De-Silanes, F., \& Shleifer, A. 2006. What works in securities laws? The Journal of Finance, 61(1): 1-32.

La Porta, R., Lopez-de-Silanes, F., \& Shleifer, A. 2008. The Economic consequences of legal origins. Journal of Economic Literature, 46(2): 285-332.

Lakshman, N. 2003. The political economy of good governance for poverty alleviation policies. ERD Working Paper No. 39. Manila: Asian Development Bank.

Lee, S. H., Yamakawa, Y., Peng, M. W., \& Barney, J. B. 2011. How do bankruptcy laws affect entrepreneurship development around the world? Journal of Business Venturing, 26(5): 505520.

Lerner, J., \& Schoar, A. 2005. Does legal enforcement affect financial transactions? The contractual channel in private equity. Quarterly Journal of Economics, 120(1): 223-246.

Levie, J., \& Autio, E. 2011. Regulatory burden, rule of law, and entry of strategic entrepreneurs: An international panel study. Journal of Management Studies, 48(6): 1392-1419.

Lewis, W. A. 1954. Economic development with unlimited supplies of labor. In A. N. Agarwala, \& S. P. Singh (Eds.), The economics of underdevelopment. London: Oxford University Press.

Li, Q., \& Resnick, A. 2003. Reversal of fortunes: Democratic institutions and foreign direct investment inflows to developing countries. International Organization, 57(1): 175-212.

Licht, A., \& Siegel, J. I. 2006. Social dimensions of entrepreneurship In M. Casson, \& B. Yeung (Eds.), Oxford handbook of entrepreneurship. Oxford: Oxford University Press.

McMillan, J., \& Woodruff, C. 2002. The central role of entrepreneurs in transition economies. Journal of Economic Perspectives, 16(3): 153-170.

Minniti, M., Bygrave, W. D., \& Autio, E. (2006). Global Entrepreneurship Monitor GEM 2005 executive report. (M. Minniti, Ed.). London: Global Entrepreneurship Research Association (GERA).

North, D. 1990. Institutions, institutional change and economic performance. Cambridge: Cambridge University Press.

North, D. C. 1993. Institutions and credible commitment. Journal of Institutional and Theoretical Economics/Zeitschrift Fur Die Gesamte Staatswissenschaft, 149(1): 11-23.

O’Brien, J. P., Folta, T. B., \& Johnson, D. R. 2003. A real options perspective on entrepreneurial entry in the face of uncertainty. Managerial \& Decision Economics, 24(8): 515-533.

OECD \& Eurostat. 2005. Oslo manual: Guildlines for collecting and interpreting innovation daraThird edition. Paris: OECD.

Oxfam. 2012. Facing the facts: Acknowledging the informal economy in anti-poverty policies and services. Reseach paper. http://wiego.org/publications/facing-facts-acknowledging-informaleconomy-anti-poverty-policies-and-services. Accessed on Aug. 1, 2013. 
Peng, M. W. 2002. Towards an institution-based view of business strategy. Asia Pacific Journal of Management, 19(2-3): 251-267.

Peng, M. W., \& Heath, P. S. 1996. The growth of the firm in planned economies in transition: Institutions, organizations, and strategic choice. Academy of Management Review, 21(2): 492-528.

Peng, M. W., Sun, L. S., Pinkham, B., \& Chen, H. 2009. The institution-based view as a third leg for a strategy tripod. Academy of Management Perspectives, 23(3): 63-81.

Perry, G. E., \& Maloney, W. F. 2007. Overview: Informality: Exit and exclusion. In G. E. Perry, W. F. Maloney, O. S. Arias, P. Fajnzylber, A. D. Mason, \& J. Saavedra-Chanduvi (Eds.), Informality: Exit and exclusion. Washington DC: World Bank.

Piggott, J., \& Whalley, J. 2001. VAT base broadening, self-supply, and the informal sector. The American Economic Review, 91(4): 1084-1094.

Puddington, A. 2012. Freedom in the world 2012: The Arab uprisings and their global repercussions. Freedom House Report. http://www.freedomhouse.org/report/freedomworld/freedom-world-2012. Accessed on Aug. 1, 2013.

Puddington, A. 2013. Freedom in the world 2013: Democratic breakthroughs in the balance. Freedom House Report. http://www.freedomhouse.org/report/freedom-world/freedomworld-2013. Accessed on Aug. 1, 2013.

Ravallion, M. 2007. Economic growth and poverty reduction: Do poor countries need to worry about inequality? 2020 Focus Brief on the World’s Poor and Hungry People, International Food Policy Research Institute, Washington, DC. http://www.ifpri.org/publication/economic-growth-and-poverty-reduction. Accessed on Aug. 1, 2013.

Reddy, M. 2007. Modelling poverty dimensions of urban informal sector operators in a developing economy. European Journal of Development Research, 19(3): 459-479.

Reynolds, P., Storey, D. J., \& Westhead, P. 1994. Cross-national comparisons of the variation in new firm formation rates. Regional Studies, 28(4): 443-456.

Root, H. L. 1996. Small countries, big lessons: Governance, and the rise of East Asia. New York: Oxford University Press.

Russell, S. S., Clark, J. R., \& Dwight, R. L. 2007. Freedom, barriers to entry, entrepreneurship, and economic progress. Rev Austrian Econ, 20: 221-236.

Schneider, F., \& Buehn, A. 2009. Shadow economies and corruption all over the world: Revised estimates for 120 countries. Economics: The Open-Access, Open-Assessment E-Journal, Vol. 1, 2007-9 (Version 2):1-53. http://dx.doi.org/10.5018/economics-ejournal.ja.2007-9

Schneider, F., Buehn, A., \& Montenegro, C. E. 2010. New estimates for the shadow economies all over the world. International Economic Journal, 24: 443-461.

Shane, S. 1996. Explaining variation in rates of entrepreneurship in the United States: 1899-1988. Journal of Management, 22(5): 747-781. 
Shane, S. 2009. Why encouraging more people to become entrepreneurs is bad public policy. Small Business Economics, 33(2): 141-149.

Spamann, H. 2008. 'Law and finance' revisited: Discussion Paper No. 12, Harvard Law School John M. Olin Center, Cambridge, MA. Available at SSRN: http://ssrn.com/abstract=1095526 or http://dx.doi.org/10.2139/ssrn.1095526.

Stel, A., Storey, D. J., \& Thurik, R. 2007. The effect of business regulations on nascent and young business entrepreneurship. Small Business Economics, 28(2-3): 171-186.

Stenholm, P., Acs, Z. J., \& Wuebker, R. 2013. Exploring country-level institutional arrangements on the rate and type of entrepreneurial activity. Journal of Business Venturing, 28(1): 176193.

Tebaldi, E., \& Mohan, R. 2010. Institutions and poverty. The Journal of Development Studies, 46(6): 1047-1066.

Wan, G., \& Sebastian, I. 2011. Poverty in Asia and the Pacific: An update. Economics Working Paper, No. 267. Manila: Asian Development Bank.

Webb, J. W., Bruton, G. D., Tihanyi, L., \& Ireland, R. D. 2013. Research on entrepreneurship in the informal economy: Framing a research agenda. Journal of Business Venturing, 28(5): 598614.

Webb, J. W., Tihanyi, L., Ireland, R. D., \& Sirmon, D. G. 2009. You say illegal, I say legitimate: Entrepreneurship in the informal economy. Academy of Management Review, 34(3): 492510.

Weingast, B. R. 1995. The economic role of political institutions: Market-preserving federalism and economic development. The Journal of Law, Economics, \& Organization, 11(1):1-31.

Weingast, B. R. 1997. The political foundations of democracy and the rule of law. American Political Science Review, 91(2): 245-263.

Wennekers, S., \& Thurik, R. 1999. Linking entrepreneurship and economic growth. Small Business Economics, 13(1): 27-55.

Williams, C. C. 2005. Small businesses in the informal economy: Making the transition to the formal economy - Evidence and key stakeholder opinion. Samll Business Council Report. http://www.academia.edu/200717/Small_Businesses_in_the_informal_Economy. Accessed on Aug. 1, 2013.

Williams, C. C. 2006. The hidden enterprise culture: Entrepreneurship in the underground economy. Cheltenham: Edward Elgar.

Williams, C. C. 2008. Beyond necessity-driven versus opportunity-driven entrepreneurship: A study of informal entrepreneurs in England, Russia and Ukraine. International Journal of Entrepreneurship and Innovation, 9(3): 157-166.

Williams, C. C., \& Nadin, S. 2010. Entrepreneurship and the informal economy: An overview. Journal of Developmental Entrepreneurship, 15(4): 361-378. 
Zellner, A. 1962. An efficient method of estimating seemingly unrelated regressions and tests for aggregation bias. Journal of the American statistical Association, 57(298): 348-368. 


\begin{tabular}{|c|c|c|}
\hline Country & $\begin{array}{l}\text { Formal } \\
\text { Entrepreneurship }\end{array}$ & $\begin{array}{l}\text { Informal } \\
\text { Entrepreneurship }\end{array}$ \\
\hline Australia & 0.63 & 1.08 \\
\hline Israel & 0.47 & 0.48 \\
\hline Japan & 0.14 & 0.28 \\
\hline Kazakhstan & 0.35 & 1.42 \\
\hline Korea & 0.16 & 2.01 \\
\hline New Zealand & 2.19 & 0.75 \\
\hline Turkey & 0.10 & 1.03 \\
\hline Hong Kong & 1.29 & 0.06 \\
\hline India & 0.01 & 1.54 \\
\hline Indonesia & 0.02 & 3.63 \\
\hline Jordan & 0.06 & 1.86 \\
\hline Malaysia & 0.25 & 1.09 \\
\hline Pakistan & 0.00 & 0.90 \\
\hline Philippines & 0.02 & 5.51 \\
\hline Russia & 0.40 & 0.34 \\
\hline Singapore & 0.47 & 0.44 \\
\hline Thailand & 0.06 & 4.51 \\
\hline Vanuatu & 0.42 & 9.64 \\
\hline Asia-Pacific countries & 0.39 & 2.03 \\
\hline Uruguay & 0.29 & 0.95 \\
\hline Peru & 0.22 & 2.86 \\
\hline Panama & 0.03 & 1.12 \\
\hline Mexico & 0.06 & 1.05 \\
\hline Guatemala & 0.07 & 3.16 \\
\hline Costa Rica & 1.15 & 0.20 \\
\hline Colombia & 0.10 & 3.68 \\
\hline Chile & 0.22 & 1.52 \\
\hline Brazil & 0.21 & 2.76 \\
\hline Bolivia & 0.04 & 4.49 \\
\hline Argentina & 0.05 & 1.82 \\
\hline $\begin{array}{l}\text { Latin American and Caribbean } \\
\text { countries }\end{array}$ & 0.21 & 2.17 \\
\hline Zambia & 0.08 & 6.87 \\
\hline Uganda & 0.06 & 7.19 \\
\hline Tunisia & 0.12 & 1.92 \\
\hline South Africa & 0.11 & 0.65 \\
\hline Morocco & 0.13 & 3.05 \\
\hline Ghana & 0.06 & 8.70 \\
\hline Egypt & 0.01 & 1.63 \\
\hline Algeria & 0.04 & 1.84 \\
\hline African countries & 0.08 & 3.98 \\
\hline
\end{tabular}




\begin{tabular}{|c|c|c|}
\hline Slovenia & 0.34 & 0.27 \\
\hline Serbia & 0.21 & 0.85 \\
\hline Romania & 0.56 & 0.35 \\
\hline Poland & 0.05 & 0.80 \\
\hline Macedonia & 0.65 & 1.11 \\
\hline Latvia & 0.61 & 0.50 \\
\hline Hungary & 0.42 & 0.57 \\
\hline Czech Republic & 0.23 & 0.33 \\
\hline Croatia & 0.27 & 0.32 \\
\hline Austria & 0.07 & 0.39 \\
\hline Belgium & 0.39 & 0.09 \\
\hline Canada & 0.69 & 0.57 \\
\hline Denmark & 0.57 & 0.36 \\
\hline Finland & 0.30 & 0.45 \\
\hline France & 0.29 & 0.22 \\
\hline Germany & 0.12 & 0.46 \\
\hline Greece & 0.09 & 0.75 \\
\hline Iceland & 1.50 & 0.37 \\
\hline Ireland & 0.60 & 0.67 \\
\hline Italy & 0.19 & 0.35 \\
\hline Netherlands & 0.27 & 0.54 \\
\hline Norway & 0.44 & 0.73 \\
\hline Portugal & 0.48 & 0.47 \\
\hline Spain & 0.47 & 0.50 \\
\hline Sweden & 0.35 & 0.35 \\
\hline UK & 0.88 & 0.21 \\
\hline United States & 0.24 & 0.99 \\
\hline Montenegro & 0.37 & 0.58 \\
\hline Bosnia and Herzegovina & 0.07 & 0.65 \\
\hline Switzerland & 0.33 & 0.66 \\
\hline OECD countries & 0.43 & 0.62 \\
\hline Transition countries & 0.37 & 0.62 \\
\hline
\end{tabular}

This table is produced based on data estimated by the method discussed in the Variables and Measures section. 
Table 2 Descriptive Statistics and Correlation Matrix

\begin{tabular}{llllllllll}
\hline Variable & 1 & 2 & 3 & 4 & 5 & 6 & 7 & 8 & 9 \\
\hline Mean & 0.48 & 1.25 & 3.49 & 72.84 & 67.71 & 0.40 & 4.31 & 1450 & 7.66 \\
Std. Dev. & 0.59 & 1.59 & 2.29 & 15.65 & 5.08 & 1.81 & 3.78 & 1820 & 4.89 \\
Min & 0.003 & 0.06 & 1 & 43.1 & 52.91 & -1.82 & -7.81 & 0.47 & 1.11 \\
Max & 2.37 & 9.64 & 7 & 100 & 82.29 & 10.51 & 14.20 & 9070 & 23.18 \\
\hline 1 Formal entrepreneurship & 1 & & & & & & & & \\
2 Informal entrepreneurship & -0.18 & 1 & & & & & & & \\
3 Political institutions & 0.15 & -0.10 & 1 & & & & & & \\
4 Economic institutions & 0.34 & -0.19 & 0.15 & 1 & & & & & \\
5 Population size (working-age), millions & 0.10 & -0.14 & -0.37 & 0.31 & 1 & & & & \\
6 Population growth & 0.12 & 0.21 & 0.03 & 0.03 & -0.46 & 1 & & & \\
7 GDP growth & 0.03 & 0.12 & -0.28 & -0.15 & 0.08 & 0.19 & 1 & & \\
8 GDP (ppp), billions\$ & -0.37 & -0.27 & 0.22 & -0.19 & 0.02 & -0.61 & -0.28 & 1 \\
9 Establishment rate & -0.07 & 0.77 & 0.16 & -0.05 & -0.20 & 0.22 & 0.10 & -0.16 & 1 \\
\hline
\end{tabular}


Table 3A Effects of Economic and Political Institutions on Entry into Formal and Informal Entrepreneurship (Asia-Pacific Countries)

\begin{tabular}{|c|c|c|c|}
\hline & \multicolumn{3}{|c|}{ Formal Entrepreneurship } \\
\hline & Model 1 & Model 2 & Model 3 \\
\hline Political institutions & & $0.43(0.17) *$ & $0.3(0.17) \dagger$ \\
\hline Economic institutions & & $0.3(0.15) \dagger$ & $0.44(0.16) * *$ \\
\hline Political * Economic institutions & & & $0.32(0.14) *$ \\
\hline Working-age population & $0.23(0.18)$ & $0.21(0.2)$ & $0.21(0.19)$ \\
\hline Population growth & $-0.12(0.32)$ & $-0.26(0.3)$ & $-0.1(0.3)$ \\
\hline GDP growth & $-0.22(0.17)$ & $-0.03(0.16)$ & $0.03(0.16)$ \\
\hline GDP (ppp) & $-0.89(0.24) * * *$ & $-0.94(0.23) * * *$ & $-0.94(0.22) * * *$ \\
\hline Establishment rate & $-0.12(0.13)$ & $-0.16(0.12)$ & $-0.19(0.12)$ \\
\hline Constant & $0.56(0.19) * *$ & $0.44(0.19) *$ & $0.34(0.19) \dagger$ \\
\hline Number of observations & 74 & 74 & 74 \\
\hline Obs. Per group: Min & 1 & 1 & 1 \\
\hline Avg & 4.2 & 4.2 & 4.2 \\
\hline Max & 10 & 10 & 10 \\
\hline $\mathrm{R}^{2}$ & 0.22 & 0.33 & 0.37 \\
\hline \multirow[t]{2}{*}{$\mathrm{Chi}^{2}$} & $26.56^{* * *}$ & $43.84^{* * *}$ & $52.45^{* * *}$ \\
\hline & \multicolumn{3}{|c|}{ Informal Entrepreneurship } \\
\hline Political institutions & & $-0.21(0.1) *$ & $-0.17(0.1) \dagger$ \\
\hline Economic institutions & & $-0.18(0.09) *$ & $-0.22(0.09) *$ \\
\hline Political * Economic institutions & & & $-0.11(0.09)$ \\
\hline Working-age population & $-0.09(0.1)$ & $-0.05(0.11)$ & $-0.05(0.11)$ \\
\hline Population growth & $-0.2(0.19)$ & $-0.13(0.17)$ & $-0.19(0.18)$ \\
\hline GDP growth & $0.04(0.1)$ & $-0.07(0.1)$ & $-0.1(0.1)$ \\
\hline GDP (ppp) & $-0.27(0.14) \dagger$ & $-0.25(0.13) \dagger$ & $-0.26(0.13) *$ \\
\hline Establishment rate & $0.75(0.07) * * *$ & $0.76(0.07) * * *$ & $0.77(0.07) * * *$ \\
\hline Constant & $0.04(0.11)$ & $0.11(0.11)$ & $0.16(0.12)$ \\
\hline Number of observations & 67 & 67 & 67 \\
\hline Obs. per group: Min & 1 & 1 & 1 \\
\hline Avg & 3.9 & 3.9 & 3.9 \\
\hline Max & 10 & 10 & 10 \\
\hline $\mathrm{R}^{2}$ & 0.65 & 0.68 & 0.69 \\
\hline $\mathrm{Chi}^{2}$ & $128.81^{* * *}$ & $146.06 * * *$ & $151.92 * * *$ \\
\hline
\end{tabular}

${ }^{* * *} \mathrm{p}<0.001,{ }^{* *} \mathrm{p}<0.01,{ }^{*} \mathrm{p}<0.05 . \dagger \mathrm{p}<0.1$

All variables included in the regression models are standardized.

Standard errors are reported in parentheses. 
Table 3B Effects of Economic and Political Institutions on Entry into Formal and Informal Entrepreneurship (All 67 Countries)

\begin{tabular}{|c|c|c|c|}
\hline & \multicolumn{3}{|c|}{ Formal Entrepreneurship } \\
\hline & Model 4 & Model 5 & Model 6 \\
\hline Political institutions & & $0.17(0.06) * *$ & $0.12(0.06) \dagger$ \\
\hline Economic institutions & & $0.41(0.05) * * *$ & $0.34(0.06) * * *$ \\
\hline Political * Economic institutions & & & $0.2(0.06) * *$ \\
\hline Working-age population & $0.42(0.06) * * *$ & $0.29(0.06) * * *$ & $0.34(0.06) * * *$ \\
\hline Population growth & $0.45(0.09) * * *$ & $0.34(0.09) * * *$ & $0.37(0.09) * * *$ \\
\hline GDP growth & $-0.06(0.05)$ & $0.05(0.05)$ & $0.06(0.05)$ \\
\hline GDP (ppp) & $-0.33(0.08) * * *$ & $-0.3(0.08) * * *$ & $-0.34(0.08) * * *$ \\
\hline Establishment rate & $-0.08(0.05) \dagger$ & $-0.03(0.05)$ & $-0.04(0.04)$ \\
\hline Constant & $0.06(0.04)$ & $-0.19(0.05) * * *$ & $-0.2(0.05) * * *$ \\
\hline Number of observations & 345 & 345 & 345 \\
\hline Obs. per group: Min & 1 & 1 & 1 \\
\hline Avg & 5.3 & 5.3 & 5.3 \\
\hline Max & 10 & 10 & 10 \\
\hline $\mathrm{R}^{2}$ & 0.14 & 0.28 & 0.3 \\
\hline \multirow[t]{2}{*}{$\mathrm{Chi}^{2}$} & $79.15^{* * *}$ & $167.98 * * *$ & $185.43 * * *$ \\
\hline & \multicolumn{3}{|c|}{ Informal Entrepreneurship } \\
\hline Political institutions & & $-0.29(0.04) * * *$ & $-0.28(0.04) * * *$ \\
\hline Economic institutions & & $-0.13(0.04) * * *$ & $-0.11(0.04) * *$ \\
\hline Political * Economic institutions & & & $-0.06(0.04)$ \\
\hline Working-age population & $-0.37(0.04) * * *$ & $-0.33(0.04) * * *$ & $-0.34(0.04) * * *$ \\
\hline Population growth & $0.14(0.07) *$ & $0.12(0.06) \dagger$ & $0.11(0.06)$ \\
\hline GDP growth & $0.1(0.03) * *$ & $0.04(0.03)$ & $0.04(0.03)$ \\
\hline GDP (ppp) & $0.02(0.02)$ & $0.04(0.02) \dagger$ & $0.04(0.02) *$ \\
\hline Establishment rate & $0.62(0.03) * * *$ & $0.59(0.03) * * *$ & $0.59(0.03) * * *$ \\
\hline Constant & $-0.03(0.03)$ & $0.16(0.04) * * *$ & $0.17(0.04) * * *$ \\
\hline Number of observations & 329 & 329 & 329 \\
\hline Obs. per group: Min & 1 & 1 & 1 \\
\hline Avg & 5 & 5 & 5 \\
\hline Max & 10 & 10 & 10 \\
\hline $\mathrm{R}^{2}$ & 0.70 & 0.748 & 0.75 \\
\hline $\mathrm{Chi}^{2}$ & $790.8^{* * *}$ & $964.57 * * *$ & $972.71 * * *$ \\
\hline
\end{tabular}

${ }^{* * *} \mathrm{p}<0.001,{ }^{* *} \mathrm{p}<0.01,{ }^{*} \mathrm{p}<0.05 . \dagger \mathrm{p}<0.1$

All variables included in the regression models are standardized.

Standard errors are reported in parentheses. 
Figure 1 Interaction Effects of Economic and Political Institutions on Entry into Formal Entrepreneurship (Asia-Pacific Countries)

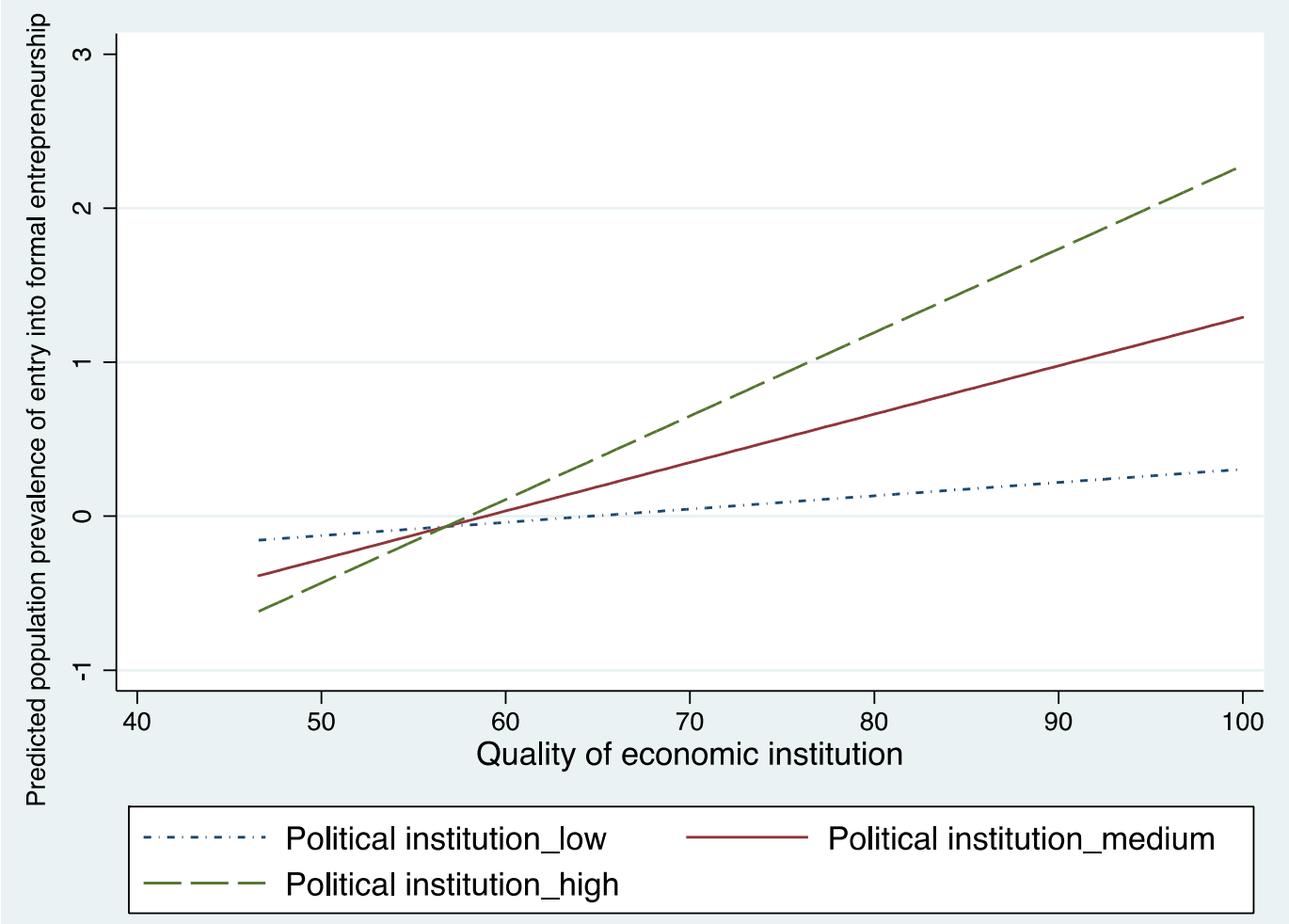

